PRZEGLĄD NAUK HISTORYCZNYCH 2017, R. XVI, NR 1

http://dx.doi.org/10.18778/1644-857X.16.01.03

PRZEMYSŁAW WAINGERTNER

UNIWERSYTET ŁÓDZKI*

\title{
Ekspozytury i wpływy Związku Młodzieży Polskiej „Zet” w okresie zaborów (1886-1914)
}

Streszczenie. W 1886 r. na Uniwersytecie Warszawskim powstał tajny Związek Młodzieży Polskiej „Zet” (ZMP). W ciąu trzech dekad stał się on sprawnie zorganizowana i działajacą struktura, mająca swoje placówki w ośrodkach akademickich, w których studiowali Polacy - na ziemiach polskich wszystkich trzech zaborów, w Rosji oraz w Europie Zachodniej. Program Zwiazku wzywał młodzież do walki o niepodległa, zjednoczoną, demokratyczną, samorządna, sprawiedliwą społecznie oraz tolerancyjną Rzeczpospolitą. Członkowie ZMP, dążąc do wpływu na młodych Polaków, prowadzili działalność polegająca na zakładaniu i inspirowaniu związków akademickich, uczniowskich, młodzieży robotniczej i chłopskiej. Starali się również penetrować już istniejące struktury "dorosłego" społeczeństwa. Do grona tych organizacji należały: „Czerwona Róża”, „X”, „Pet”, Towarzystwa Tomasza Zana, Grupy Narodowe, Organizacja Młodzieży Narodowej, „Eleuzis”, Związek Towarzystw Polskich w Niemczech „Unitas”, Zjednoczenie Towarzystw Młodzieży Polskiej Zagranica, Związek Młodzieży Rzemieślniczej, Narodowy Zwiazek Robotniczy, Narodowy Związek Chłopski, Liga Oświaty Ludowej, Towarzystwo Oświaty Narodowej i Drużyny Bartoszowe. Poszerzały one wpływy ZMP.

Słowa kluczowe: historia Polski XIX-XX w., ruchy społeczne i polityczne na ziemiach polskich, Związek Młodzieży Polskiej „Zet”.

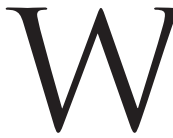

1886 r. na Uniwersytecie Warszawskim powstał - utworzony przez zainspirowanych idea niepodległościowa młodych polskich studentów - zakonspirowany Związek Młodzieży Polskiej „Zet” (dalej: ZMP). W ciagu niespełna trzech dekad stał się on sprawnie zorganizowana i działająca struktura, mająca swoje placówki w kilkunastu ośrodkach akademickich, w któ-

* Wydział Filozoficzno-Historyczny, Instytut Historii, Katedra Historii Polski Najnowszej, e-mail: wajn@op.pl. 
rych studiowali Polacy - nie tylko na ziemiach polskich wszystkich trzech zaborów, lecz także w głębi Rosji oraz w Europie Zachodniej. Środowiska ZMP funkcjonowały również na polskiej prowincji - w mniejszych miastach, $z$ których pochodzili i w których również organizowali się zetowcy. W przededniu I wojny światowej organizacja liczyła ponad pół tysiąca członków.

Program Związu wzywał młodzież do walki o niepodległa, zjednoczona, demokratyczna, ufundowana na idei poszanowania praw obywatelskich i szerokiego samorządu, sprawiedliwą społecznie oraz tolerancyjna narodowościowo i religijnie Rzeczpospolita. Walkę tę „bracia” zetowi rozumieli zarówno jako bieżąca pracę samokształceniowa, formacyjną, organizujaca i mobilizująca młode pokolenie wokół haseł patriotycznych, nakierowana na „wszechstanowe” zjednoczenie narodu i jego awans cywilizacyjny, jak i irredentystyczny czyn zbrojny, podjęty w sprzyjającej sytuacji międzynarodowej.

Zetowcy, dażąc do uzyskania wpływu na kształtowanie postaw młodych Polaków, prowadzili działalność obejmująca zarówno ziemie polskie, jak i zagranicę, a polegająca na zakładaniu, inspirowaniu lub włączaniu się w prace związków akademickich, uczniowskich, młodzieży robotniczej i chłopskiej. Starali się również współtworzyć nowe lub penetrować istniejace struktury „dorosłego” społeczeństwa. Wspomniane poczynania doprowadziły do ukształtowania się sieci organizacji o charakterze zarówno konspiracyjnym, jak i jawnym, kierowanych lub inspirowanych przez „braci” zetowych. $Z$ ich rzeczywistej roli niewtajemniczeni członkowie tych organizacji, nienależący do ZMP, nie zdawali sobie sprawy.

Kiedy po zdławieniu powstania styczniowego carski zaborca przystapił do intensywnej rusyfikacji szkolnictwa, polska młodzież podjęła działania obronne, tworząc tajne koła samokształceniowe. Koła te zawiązały się samorzutnie niemal we wszystkich gimnazjach Królestwa Polskiego. Uczono w nich historii Polski, pogłębiano wiedzę o ojczystym języku i poznawano dzieła literatury polskiej. Na prowadzonych w trakcie ich spotkań dyskusjach młodzież kształtowała swoje poglądy ideowo-polityczne. Realizując zamysł formowania poglądów i kształcenia młodzieży szkolnej, „Zet” podjął próbę koordynowania działalności kół, a następnie zespolenia ich w jedna sieć. Efektem tych poczynań było stworzenie w 1896 r. Związku Kół Gimnazjalnych, który działał przez trzy lata ${ }^{1}$.

${ }^{1}$ A. Wierusz, Ruch niepodległościowy kształcacej sie młodzieży b. zaboru pruskiego, [w:] Pamiętnik I Zjazdu Niepodległościowców byłej dzielnicy pruskiej 
Natomiast jeszcze w 1898 r. zetowcy Stefan Rowiński i Władysław Bolewski założyli w tajnych kółkach samokształceniowych, działajacych w zaborze pruskim, wewnętrzna konspirację pod nazwą „Czerwona Róża”, której członkowie określali się mianem filomatów, nawiązując do romantycznej i mickiewiczowskiej tradycji. Spotkanie założycielskie było zarazem przez jego uczestników traktowane jako pierwszy zjazd nowej, tajnej organizacji. Działania te inspirowali i koordynowali zetowcy, którzy roztoczyli również opiekę merytoryczną nad pracami poszczególnych placówek „Czerwonej Róży”.

Drugi zjazd nowego konspiracyjnego stowarzyszenia odbył się w grudniu 1899 r. w Poznaniu. Przyjęto uchwałę nakazująca wszystkim kołom odbywanie samokształceniowych lekcji $z$ historii i geografii Polski oraz prowadzenie abonamentu wskazanych pism (wśród nich zetowej „Teki”), wreszcie wprowadzenie kary pieniężnej za używanie germanizmów podczas zebrań. Wszyscy członkowie otrzymali nakaz uczęszczania na gimnazjalne lekcje języka polskiego oraz obowiązek przygotowywania prac pisemnych dotyczących problematyki podanej przez prezesów kół. Ponadto opracowano zarys programu tajnego kursu obejmującego historię Polski i dzieje literatury ojczystej ze szczególnym podkreśleniem okresu porozbiorowego.

W 1900 r. „Czerwona Róża” skupiała liczne koła z Białogardu, Brodnicy, Bydgoszczy, Chełmna, Chojnic, Gniezna, Kcyni, Krotoszyna, Leszna, Nakła, Ostrowa Wielkopolskiego, Poznania, Rogoźna, Śremu, Wagrowca i Torunia. Wśród najaktywniejszych działaczy organizacji znaleźli się Bolesław Szulczewski (prezes „Czerwonej Róży” u schyłku XIX w.) i Bronisław Szulczewski. Prace kół, ich tematykę i charakter starali się nadzorować zetowcy. W 1901 r. władze pruskie wykryły „Czerwona Różę” i wytoczyły procesy filomatom, a także akademikom spod znaku „Zetu” współpracujacym $z$ kołami, a zarazem nadającym ton ich poczynaniom. Równocześnie jednak od 1900 r. struktury „Czerwonej Róży” zaczęły powstawać w Galicji i Królestwie Polskim. W Kongresówce działały poczatkowo pod nazwa organizacji „X”, a od 1902 r. jako Zwiazek Młodzieży Polskiej „Przyszłość” („Pet”). Kierowała nim specjalna Komisja Gimnazjalna ZMP. „Pet” - organizacja programowo ogól-

w Poznaniu w dniu 14 I 1934 roku, Poznań 1935, s. 48-54; C. De mel, Z genezy Związku Młodej Polski w Wielkopolsce, „Studia i Materiały do Dziejów Wielkopolski i Pomorza" 1977, t. XII, z. 24, s. 158-163. 
nopolska - zajęła stopniowo w Królestwie Polskim i Galicji miejsce osłabionej aresztowaniami „Czerwonej Róży”2.

Do nowego stowarzyszenia należeli wybitni, sprawdzeni i najbardziej aktywni członkowie poszczególnych kół gimnazjalnych. Zadaniem „Petu” było pogłębianie ideologii niepodległościowej oraz znajomości zagadnień społecznych wśród młodzieży szkolnej, utrzymywanie kontaktu między petowcami na terenie całej Polski w celu nadawania pracy politycznej i samokształceniowej jednolitej linii, wyrabianie silnych charakterów i gotowości do poświęceń dla sprawy narodowej oraz przygotowanie młodzieży uczniowskiej do walki zbrojnej, bez której odzyskanie niepodległości miało być - według działaczy „Przyszłości” i koordynujących ich poczynania zetowców - niemożliwe.

Trzeba dodać, że umiejętności uzyskane w toku zebrań petowych - analizy tekstów, wygłaszania przemówień, argumentowania i dokonywania oceny sytuacji społecznej i politycznej - były następnie rozwijane na ostatnim szczeblu drabiny organizacyjnej, która stanowić miały dla petowców w przyszłości zebrania kół akademickich „Zetu”. Na tajnych spotkaniach petowcy czytali fragmenty i dyskutowali przesłanie pism politycznych założyciela Ligi Polskiej, Teodora Tomasza Jeża, czyli Zygmunta Miłkowskiego (m.in. traktatu Rzecz o obronie czynnej i skarbie narodowym), niepodległościowca i spółdzielcy Stanisława Szczepańskiego (Idea Polski), Romana Dmowskiego (Myśli nowoczesnego Polaka), Zygmunta Balickiego (Egoizm narodowy wobec etyki) i Stanisława Brzozowskiego (Legenda Młodej Polski) ${ }^{3}$.

"Pet” miał nie tylko ideologiczne, lecz także kadrowe powiąania $z$ „Zetem”. Koła „Petu” były kierowane przez „braci” zetowych mających duże uprawnienia organizacyjne, łącznie $z$ prawem bez-

${ }^{2}$ Biblioteka Zakładu Narodowego im. Ossolińskich [dalej: BOss.], Rękopisy, sygn. 15951 II, S. Szwedowski, „Początki pamiętnika po raz IV-ty”, s. 26-27; R. Wapiński, Pokolenia Drugiej Rzeczypospolitej, Wrocław 1991, s. 153, 157; J. Rakow s ki, Zetowcy i piłsudczycy (1), „Zeszyty Historyczne” [Paryż] 1981, z. 54, s. 11-12, 18-19; T.W. Now a cki, Zet-ideowy kręostup ZPMD, [w:] Zwiazek Pol skiej Młodzieży Demokratycznej podczas II Rzeczypospolitej i II wojny światowej, red. J. Pietrusza, Kraków 1998, s. 31-32; K. Rat aj ska, Dziedzice filomatyzmu, Wrocław 1987, s. 195-200; B. Hillebrandt, Polskie organizacje młodzieżowe XIX i XX wieku. Zarys historii, Warszawa 1986, s. 21-22. O aktywności „Petu” por. np. J. Jaruzelski, Stanisław Cat-Mackiewicz 1896-1966. Wilno-Londyn-Warszawa, Warszawa 1994, s. 21.

${ }^{3}$ T.W. Nowacki, Zwycięska walka młodzieży o szkołe polska 1901-1917, „Niepodległość i Pamięć” 2007, nr 2, s. 45. 
względnego sprzeciwu wobec uchwał koła. W strukturze „Przyszłości" przyjęto też trójstopniowy - bliźniaczo podobny do zetowego - układ konspiracji. Podzielono członków organizacji na „promienistych”, „filaretów” i „filomatów”. Konspiracja ogniw najwyższego stopnia wtajemniczenia była bardzo głęboka, skrupulatnie przestrzegano zasady jej tajności i nieujawniania wobec działaczy niższych stopni. Dzięki temu do momentu odzyskania przez Polskę niepodległości żadne $z$ kół filomackich „Petu” nie zostało wykryte przez policję państw zaborczych. Nadzór nad obliczem ideowym i bieżącą działalnościa „Petu” sprawowała Dyrekcja ${ }^{4}$.

Petowcy działali prężnie m.in. w Łodzi, gdzie współdziałali z miejscowymi socjalistami. Wspólnie $z$ nimi inicjowali i prowadzili strajk szkolny 1905 r., a następnie bojkot szkół rosyjskich Ziemi Obiecanej przez polska młodzież. Organizowali również akcję towarzyskiego bojkotu uczęszczających do rosyjskich placówek uczniów, a nawet ich rodziców ${ }^{5}$. Dynamicznie działał „Pet” także w Radomskiem. W początkach XX w. petowcy znaleźli się m.in. w licznej grupie młodzieży relegowanej przez władze oświatowe $z$ radomskiego gimnazjum za działalność patriotyczno-wychowawcza. Od jesieni 1904 r. delegatem tzw. Dyrekcji „Petu” na gubernię radomska był związany z „Zetem” student Tomasz Millak. Struktury petowe funkcjonowały także w szkołach Sandomierza oraz w placówkach lubelskich, włocławskich i łowickich ${ }^{6}$.

Natomiast w zaborze pruskim koła „Czerwonej Róży” przekształciły się w latach 1907-1908 w Towarzystwa Tomasza Zana (dalej: TTZ) ${ }^{7}$. Celem tej organizacji było, według jej statutu, rozbudzanie i pielęgnowanie w młodzieży miłości i poczucia obowiązku względem ojczyzny oraz ideowe kształtowanie działaczy gotowych do pracy obywatelskiej, a w razie potrzeby - do walki zbrojnej o niepodległość Polski. W powstaniu, a następnie rozbudowie TTZ istotną rolę - jako mentorzy, instruktorzy czy też specjalni komisarze - odegrali działacze delegowani przez ZMP, m.in. Emil Cyran, Szczepan

${ }^{4}$ B. Hillebrandt, op. cit., s. 21-22.

5 M. W oło s, „Ojczyźnie służy”. Damian Stanisław Wandycz (1892-1974), Bełchatów-Kraków-Warszawa 2015, s. 34-35.

${ }^{6}$ P.A. Tus ińs ki, Narodowa Demokracja $w$ guberni radomskiej $w$ latach 1893 1907, [w:] Dziedzictwo rewolucji 1905-1907, red. A. Żarnowska i in., WarszawaRadom 2007, s. 309.

7 J. Rakowski, op. cit., s. 12, 29-31; J. Szews, Filomaci pomorscy. Tajne zwiąki młodzieży polskiej na Pomorzu Gdańskim w latach 1830-1920, Warszawa 1992, s. 29-51. 
Gracz i Bronisław Kędzierski. Zetowcy inspirowali i koordynowali również pracę poszczególnych placówek TTZ.

Działalność organizacji regulował przyjęty w 1913 r. statut Towarzystwa, zwyczajowo określane były one mianem kół samokształceniowych. W rzeczywistości były elitarną organizacją młodzieżową $z$ ambitnymi, politycznymi celami, silna struktura i udoskonalonymi przez lata doświadczeń formami działalności merytorycznej oraz konspiracyjnej. Młodzieży wpajano „zasady żołnierza polskiego”, aby w przyszłości ofiarnie stanęła „do świętej walki orężnej o niepodległość”. Kandydat na członka TTZ składał przysięgę: „Wstępując do organizacji Filomackiej Towarzystwa Tomasza Zana, przysięgam na Boga, Ojczyznę i honor Polaka, że wszystkie sprawy organizacyjne w najgłębszej zachowam tajemnicy, że szczerym dażeniem przyczynię się, aby się wychować na dzielnego obywatela-żołnierza Polaka, przez ciagła, niestrudzona pracę samokształceniową duchową i cielesną. Tak mi dopomóż Bóg!"8.

Członkowie TTZ (analogicznie do petowców) przechodzili ponadto przez trójstopniowe wtajemniczenie. Początkowo, jako „promieniści”, mieli uświadamiać sobie „odrębność duszy polskiej” i „wyrywać ja spod wpływu germanizacyjnego”. Jeżeli „gorliwie zajmowali się sprawami polskimi”, awansowali na „filaretów”, którzy powinni „utrwalać podstawy narodowe i moralne [...], stopniowo przyzwyczajając się do pracy samodzielnej”. Po ukończeniu dwuletniego kursu i zdaniu pisemnego oraz ustnego egzaminu mogli zostać „filomatami”, by „przygotować się do przyszłej pracy obywatelskiej” w wolnej Polsce ${ }^{9}$. Grupa sprawdzonych, najbardziej aktywnych i wartościowych ideowo działaczy i członków TTZ o najwyższym stopniu wtajemniczenia była traktowana przez zetowców - uczestniczacych wszak w pracach organizacji i mających pełną orientację co do wartości poszczególnych wychowanków Towarzystw - jako środowisko, w którym werbowano przyszłych adeptów ZMP, oferując im wstapienie w szeregi konspiracji zetowej.

Działalnością TTZ kierował zarząd, składający się $z$ „urzędników": prezesa, naczelnika filomackiego, naczelnika filareckiego, bibliotekarza i skarbnika. Co pół roku odbywali oni walne zebranie. Ważnym elementem struktury Towarzystw Tomasza Zana były komisje egzaminacyjne, decydujące o awansie członków w hierarchii organizacyjnej. W skład wyższej komisji filomackiej wchodzili:

8 Cyt. za: A. Markwicz, 100 lat historii TTZ, Londyn 1975, s. 99.

9 Ibidem, s. 99. 
prezes, naczelnik filomatów i tzw. kółkowy. Komisję niższą - filarecka - stanowili: prezes, naczelnik filaretów i kółkowy. Dla potrzeb prac TTZ tworzono też tajne biblioteki. Przed 1914 r. największe spośród nich miały koła w Poznaniu oraz w Ostrowie i Gnieźnie ${ }^{10}$.

W celu zachowania konspiracji, w małych, kilkuosobowych grupach organizowano również zawody strzeleckie, wycieczki krajoznawcze i tajne harcerstwo. Prowadzono dodatkowe lekcje historii i geografii. Piętnowano używanie w mowie i piśmie germanizmów. Szczególnie czczono daty narodowych rocznic: 3 maja, 29 listopada (wybuch powstania 1830 r.) i 1 lipca (dzień podpisania w 1569 r. unii lubelskiej).

Józef Kostrzewski, wówczas członek TTZ, a później działacz ruchu zetowego wspominał: „Towarzystwo Tomasza Zana [...] miało na celu samokształcenie członków w języku polskim, historii i literaturze polskiej, tym bardziej konieczne, że w gimnazjum zniesiono już w owym czasie naukę języka polskiego jako jednego $z$ przedmiotów nauczania i zachowano lekcje tego języka jedynie jako przedmiot fakultatywny dla Niemców. Praca samokształceniowa odbywała się ze względów bezpieczeństwa w tzw. kółkach, złożonych $z$ trzech osób, którymi kierował kółkowy [...]. Historii uczyliśmy się najpierw ze szkolnego podręcznika Historii Polskiej Anatola Lewickiego używanego w szkołach galicyjskich, a następnie z Dziejów narodu polskiego Józefa Grabca [...], literatury z podręcznika Antoniego Kurpiela, a gramatyki z małej gramatyki Antoniego Małeckiego. Poza tym uczyliśmy się poprawnej pisowni, pisaliśmy wypracowania i uczyliśmy się na pamięć wierszy. Wymagania były duże i na końcu roku odbywały się egzaminy [...]. Była to więc formalna tajna szkoła polska [...]. Poza tym $z$ okazji rocznic narodowych, np. powstania styczniowego (22 I), czy listopadowego (29 XI) lub Konstytucji 3 maja odbywały się uroczyste zebrania całej organizacji, urządzane w bardzo wczesnej porze poza miastem [...]. Te wszystkie zajęcia, [były] jakkolwiek pożyteczne, bo pozwalające na zaznajomienie się $z$ przeszłością i kultura polską i stanowiące odtrutkę przeciwko germanizującemu wpływowi szkoły"11.

${ }^{10}$ Obszerniej o TTZ w: B. Halczak, Towarzystwo Tomasza Zana $w$ latach 1899-1914, Zielona Góra 1996, passim; J. Socha, Czasopisma Związu Towarzystw Tomasza Zana, „Rocznik Historii Prasy Polskiej” 2002, z. 1, s. 59-68. Materiały do dziejów TTZ też w korespondencji S. Szwedowskiego, I. Nowaka i R. Lutmana w: BN, Rękopisy, akc. 16272, S. Szwedowski, „Materiały do Zetu (listy Ignacego Nowaka do S. Szwedowskiego)", brak paginacji.

${ }^{11}$ J. Kostrzews ki, Z mego życia. Pamiętnik, Wrocław 1970, s. 31-33. 
Koła TTZ rozwijały się w poszczególnych miastach zaboru pruskiego pomyślnie. W Nakle członkowie zbierali się w domach zaufanych przyjaciół. Wygłaszali referaty poświęcone literaturze polskiej, recytowali wiersze, śpiewali pieśni patriotyczne. Program nauczania obejmował naukę języka polskiego, literatury, historii i geografii ziem polskich. Zajęcia odbywały się dwa razy w tygodniu - zawsze w innym miejscu i o innym czasie. Trudno określić precyzyjnie liczbę nakielskich „filomatów”. Władze pruskie relegowały $z$ miejscowego gimnazjum co najmniej kilku. W nakielskim TTZ współdziałali synowie ziemian, lekarzy, nauczycieli, kupców, rzemieślników i chłopów.

Z kolei w Wałczu w 1912 r. „filomaci” utworzyli nie tylko strukturę TTZ, lecz także drużynę skautowa. Koło wałeckie jako główne cele przyjęło krzewienie i utrzymanie języka polskiego, jak też zachowanie go od zniekształceń narzeczem kaszubskim i językiem niemieckim. Członkowie omawiali również zagadnienia historyczne. Ważną rolę w programie samokształceniowym odgrywał kurs geografii. Jednak podstawa była nauka literatury ojczystej. W zestawie lektur znalazły się klasyczne dzieła Adama Mickiewicza: Grażyna, Konrad Wallenrod, Powrót taty, Świtezianka, Lilie i Oda do młodości. Korzystano ze specjalnego kursu literatury polskiej, opracowanego dla użytku szkół. Członkowie TTZ mogli korzystać z tajnej biblioteki. Lekcje literatury łączono $z$ dyskusjami na temat etyki. W pracach pisemnych rozwijano zazwyczaj myśl zawarta w wybranym cytacie $z$ dzieł wielkiej polskiej literatury ${ }^{12}$.

W gimnazjum w Chojnicach tajny zwiazek młodzieży polskiej „Polonia” powstał już ok. 1830 r. W roku 1870 działalność rozpoczęło koło „Mickiewicz”. U schyłku XIX w. tajną działalność - patriotyczna i samokształceniowa - przejęli w Chojnicach działacze TTZ. Odbywali regularnie zajęcia i uroczyście obchodzili rocznice narodowe. Organizowali także wycieczki krajoznawcze. W 1896 r. podjęto rozmowy $z$ członkami kół $z$ Chełmna i Stargardu w celu połączenia działalności, lecz ostatecznie plany te, w obawie przed dekonspiracja, zarzucono. W 1901 r., w związku z zagrożeniem aresztowaniami, koło chojnickie zostało rozwiąane. Jego działacze pozostali jednak nadal zaangażowani w prace o charakterze konspiracyjnym. O wysokim merytorycznym poziomie pracy i dużej aktywności TTZ w Chojnicach może świadczyć to, że ośrodek ten został wybrany jako miejsce I zjazdu delegatów kół pomorskich

12 J. Szews, op. cit., s. 112-124. 
Towarzystw Tomasza Zana. Zjazd ten odbył się u progu I wojny światowej - 2 kwietnia 1914 r. ${ }^{13}$

Członkowie TTZ prowadzili działalność w warunkach głębokiej konspiracji wobec „świata zewnętrznego”. Statut nakazywał członkom zachowanie najwyższej ostrożności. Obowiązywały zakazy gromadzenia się w miejscach publicznych, rozmów i korespondencji o stowarzyszeniu poza kółkiem oraz wstępowania do organizacji niemieckich, a także nakazy niszczenia ocenionych prac pisemnych oraz nierzucajaccego się w oczy zachowania w szkołach. Mimo to władze niemieckich placówek oświatowych i policja wykryły kilka kół. W 1899 r. zostało zdekonspirowane tajne kółko literackie „Wiec”, a jego członków skazano na kilka godzin aresztu. Jednak zazwyczaj uczestnicy młodzieżowych konspiracji w zaborze pruskim byli karani bardziej surowo. Sankcja najczęściej była relegacja $z$ wilczym biletem, pozbawienie wolności, zakaz na całe życie podjęcia pracy w służbie państwowej, oświacie i duszpasterstwie oraz odebranie prawa do skróconej służby wojskowej.

W 1900 r. policja wykryła koła w Chełmnie, Brodnicy i Toruniu. Rozpoczęło się dochodzenie, zakończone w następnym roku tzw. procesem toruńskim, który zasięgiem śledztwa i liczbą oskarżonych ustępował jedynie procesowi filomatów wileńskich z $1823 \mathrm{r}$. Oskarżono 56 uczniów gimnazjum w Chełmnie, 9 uczniów gimnazjum w Toruniu, 19 uczniów gimnazjum w Brodnicy oraz 6 kleryków Seminarium Duchownego w Pelplinie. W trakcie śledztwa listę oskarżonych poszerzono o 22 uczniów gimnazjów w Białogardzie, Gnieźnie, Krotoszynie, Ostrowie Wielkopolskim, Rogoźnie, Śremie i Poznaniu. Ostatecznie w akcie oskarżenia znalazły się nazwiska 60 podejrzanych. Spośród oskarżonych 15 uwolniono z braku dowodów winy, 10 udzielono nagany, kilkunastu skazano na kary więzienia. Równocześnie większość sądzonych jeszcze przed rozprawą relegowano ze szkół. Represjonowani uczniowie spotkali się $z$ szerokim poparciem środowiska polskiego. W trakcie śledztwa zachowywali się godnie i solidarnie. Po ogłoszeniu wyroku obrońcy oskarżonych wnieśli apelację do Najwyższego Sądu w Lipsku, lecz 4 kwietnia 1902 r. została ona odrzucona. Oskarżonym pozostała jeszcze możliwość zwrócenia się $z$ prośbą o ułaskawienie do cesarza. $Z$ prawa tego nie skorzystali ${ }^{14}$.

13 Ibidem, s. 65-74, 173-186.

${ }^{14}$ K. Śla ski, Toruński proces filomatów pomorskich w 1901 roku, [w:] Filomaci pomorscy. Ksiega pamiatkowa Sesji Naukowej oraz Zjazdu Filomatów w Wejherowie w dniu 20 maja 1972 roku, oprac. J. Szews, Gdańsk 1975, s. 6-12. 
Kolejną ekspozytura „Zetu” na wyższych uczelniach i w szkołach stały się tajne Zjednoczenia Młodzieży Polskiej, występujące od 1905-1908 r. już jawnie jako Organizacja Młodzieży Narodowej (dalej: OMN), potocznie zwana „Młodzieżą Narodową. Do jej najwybitniejszych działaczy należeli np. Zdzisław Lechnicki, Gustaw Dreszer i Wiesław Czermiński. W ramach OMN wykształciły się następnie dwie struktury - Organizacja Młodzieży Narodowej Szkół Wyższych (dalej: OMNSW) i Organizacja Młodzieży Narodowej Szkół Średnich (dalej: OMNSŚ). Działacze „Zetu” byli wśród „oemenowców" swoistą wewnętrzną konspiracją, stanowiąc w organizacji właściwe środowisko kierownicze, określając priorytety programowe i kierunki działania „Młodzieży Narodowej” - zgodnie z ustaleniami, które zapadały w „Zecie” - oraz forsując je następnie na forum OMN.

Prowadząc działalność samokształceniową, młodzież z OMNSW i OMNSŚ, zwłaszcza w okresie rewolucji lat 1905-1907, walczyła również - mimo sprzeciwu Ligi Narodowej - o szkołę polską. Zakładano Ligi Bojkotowe, dążąc do skupienia w nich uczniów, którzy zdecydowali się przerwać naukę w państwowych placówkach. Inspirowano także manifestacje patriotyczne. Warto wspomnieć o udziale „Młodzieży Narodowej” w pogrzebach Bolesława Prusa i Stanisława Krzemińskiego, członka Rządu Narodowego z okresu powstania styczniowego, które odbyły się w $1912 \mathrm{r}^{15}$

Po 1905 r. „Zet” występował na wyższych uczelniach również za pośrednictwem tajnej organizacji pod nazwa Narodowo-Demokratyczna Młodzież Akademicka, która była kolejna organizacją młodzieżową, inspirowaną w istocie przez zetowców ${ }^{16}$.

W 1908 r. wszystkie podległe „Zetowi” koła, grupy i środowiska akademickie - złożone zarówno $z$ członków ZMP, jak i współpracujących $z$ nimi sympatyków idei niepodległościowo-narodowej - połączyły się w Związek Grup Narodowych. Była to organizacja tajna, jednak o znacznie szerszym składzie personalnym niż elitarny „Zet”. Najliczniejsze Grupy powstały w Niemczech - w Berlinie, Lipsku, Monachium i we Wrocławiu. Podporządkowane zostały

${ }^{15}$ O wpływach OMN por. T. Katelbach, Zet, „Zeszyty Historyczne” [Paryż] 1968, z. 13, s. 13; W. Baliński, Człowiek w cieniu. Tadeusz Pełczyński. Zarys biografii, Kraków 1994, s. 10; J. Bi elak, Z odległości lat. Wspomnienia $i$ sylwetki, Kraków 1979, s. 72; B. Hillebrandt, op. cit., s. 23-24.

${ }^{16}$ S. Kalabiński, F. Tych, Czwarte powstanie czy pierwsza rewolucja. Lata 1905-1907 na ziemiach polskich, Warszawa 1969, s. 93. 
Dyrekcji, która funkcjonowała na przemian w jednym $z$ czterech wymienionych miast ${ }^{17}$.

Bardzo silną Grupę Narodową stworzyli studenci wrocławscy. Obejmowała ona młodych Polaków $z$ wszystkich dzielnic Polski. Zetowcy werbowali ich na spotkaniach towarzyskich, tzw. fidulkach. Grupa liczyła nawet do 60 osób. Jej prace polityczne i samokształceniowe prowadzone były w ramach kilkunastu sekcji, m.in. historycznej, literackiej, społecznej, ekonomicznej, szkółek polskich, wakacyjnej, współpracy $z$ organizacjami polskimi na terenie Wrocławia, kursów oświatowych dla dorosłych, współpracy $z$ organizacjami robotniczymi, a od 1911 r. również wojskowej. Funkcjonował wymóg przygotowywania przez członków Grupy referatów dyskusyjnych przynajmniej raz w półroczu.

Zetowiec Maksymilian Wilimowski tak wspominał swój pierwszy kontakt - jako akademika studiujacego we Wrocławiu - z miejscową Grupa Narodowa oraz jej relacje z ZMP: „Zapisałem się na wydziale lekarskim [...]. Po kilku dniach znalazłem się w gronie kolegów ze Śląska [...]. Postanowiliśmy założyć tajne kółko, by zająć się młodzieżą, przyciagnąć kolegów ze Śląska pochodzących, szukać ich po innych uniwersytetach niemieckich oraz by zorganizować pracę samokształceniową w kilku sekcjach. W trakcie tych rozmów $z$ tymi kolegami nastapił dla mnie nagły, niespodziewany zwrot: zostałem przez kolegę Władysława Likowskiego, pochodzacego $z$ Pleszewa, a będacego już kandydatem medycyny w wyższych semestrach, wprowadzony do tajnej organizacji polskiej młodzieży akademickiej, tzw. Grupy Narodowej. Znalazłem się więc w organizacji, jaką zamierzaliśmy stworzyć [...]. Nie upłynęły trzy miesiące pracy mej w Grupie i zostałem przyjęty do "Zetu". "Zet" obejmował oczywiście znacznie szczuplejsze grono kolegów, bo zaledwie kilkunastu"18.

W szeregach Grupy Narodowej we Wrocławiu znalazł się również w początkach XX w. jako studentowi teologii Alfons Zgrzebniok - późniejszy przywódca I powstania ślasskiego. Było mu trudniej uczestniczyć w pracach konspiracyjnych, ponieważ trafił do konwiktu wrocławskiego w okresie, gdy działacze Grupy znajdowali się pod szczególnie baczną obserwacją władz szkolnych i policji. Była ona efektem podjęcia przez nich próby przeciwstawienia się po-

${ }^{17}$ F. Szymiczek, Stowarzyszenia akademickie polskiej młodzieży górnoślaskiej we Wrocławiu 1863-1918, Wrocław-Warszawa-Kraków 1963, s. 110-116.

18 Cyt. za: ibidem, s. 116. 
czynaniom księdza Johannesa Steinmanna, ówczesnego przewodniczącego konwiktu, niechętnego Polakom i nietolerancyjnego wobec przejawów politycznej i samokształceniowej aktywności polskiej młodzieży. Zgodnie ze swoimi zainteresowaniami A. Zgrzebniok $z$ Grupy Narodowej trafil wprost do referatu wojskowego „Zetu”. Działalność w szeregach konspiracji zetowej we Wrocławiu połączyła jego losy z losami innych znanych później członków Grup Narodowych i samego „Zetu”: Wojciecha Korfantego, Konstantego Wolnego, Emila Cyrana i Józefa Rostka ${ }^{19}$.

Wypada również przedstawić inne organizacje, nad którymi czuwało Koło Braterskie „Zetu” we Wrocławiu, a które stanowiły zarazem w mniejszym bądź większym stopniu zetowe ekspozytury. Wśród nich szczególne miejsce zajmowała na pół legalna, tolerowana przez władze uniwersyteckie Bratnia Pomoc Studentów Polaków. Dopiero w lecie 1912 r. senat wrocławskiego uniwersytetu wyraził formalna zgodę na zalegalizowanie tej placówki. Właściwym założycielem Bratniej Pomocy było właśnie Koło Braterskie „Zetu”. Jej pierwszym prezesem został natomiast Kazimierz Adamczyk. Druga - tym razem w pełni legalna - organizacja, powołaną do życia przez wrocławski „Zet” w 1912 r., było Towarzystwo Naukowe Byłych Studentów Polaków. Do jego zadań należało: stworzenie ośrodka myśli polskiej i utrzymanie ducha polskiego wśród Polonii wrocławskiej, pielegnowanie polskiej nauki i oświaty na terenie wrocławskim, podtrzymywanie stosunków koleżeńskich i towarzyskich między czynnymi studentami a absolwentami wszechnicy wrocławskiej i wreszcie zachowanie stałego pogotowia wśród „starszych” i młodzieży akademickiej na wypadek wojny. Stąd też każdy członek „Zetu” czy Grupy Narodowej zobowiązany był po ukończeniu studiów zgłosić swoje przystapienie do Towarzystwa.

Powyższe zadania realizowano dzięki licznym pomocniczym instytucjom i strukturom utworzonym bądź przynajmniej współzakładanym przez zetowców: bibliotece i czytelni polskiej, kursom oświatowym, szkółkom niedzielnym dla Polonii wrocławskiej oraz akcji zbiórek pieniężnych na cele społeczne. Pierwszym prezesem Towarzystwa Naukowego był Franciszek Mieczkowski, a pierwszym sekretarzem - Jerzy Pyszkowski. W poszczególnych latach towarzystwo liczyło przeciętnie po 40 członków, w tym sporą liczbę rodowitych Ślązaków.

${ }^{19}$ H. Wolna, Komendant „Rakoczy”, Warszawa 1985, s. 23. 
Z inicjatywy wrocławskiego „Zetu” powstały jeszcze w $1912 \mathrm{r}$. dwie organizacje akademickie o węższym zakresie działania - Koło Agronomów „Gleba” i Koło Medyków Polaków. Pierwsze z nich uzyskało aprobatę uniwersyteckiego senatu i pracowało legalnie. Jego prezesem został Jan Borowiak. Natomiast Koło Medyków Polaków działało jako stowarzyszenie tajne. „Gleba” była licznym stowarzyszeniem, przewodzili mu zetowcy. Koło Medyków miało za zadanie podtrzymywanie łączności między studentami medycyny a lekarzami-Polakami oraz zapoznawanie swych członków $z$ fachowym słownictwem medycznym polskim, w czym wielka pomoc okazywali młodzi akademicy $z$ Krakowa ${ }^{20}$.

Zetowcy działali także w konspiracyjnej, trójzaborowej i niepodległościowej konspiracyjnej organizacji „Eleuzis”, mającej wpływy wśród młodzieży na ziemiach polskich. Odegrała ona pewną rolę $\mathrm{w}$ obronie przed wynarodowieniem i w wychowaniu w polskości licznych robotników polskich na Ślasku i w Westfalii. Poza wysyłaniem prelegentów $z$ Krakowa do ośrodków robotniczych $\mathrm{w}$ obu tych prowincjach organizowała dla robotników kursy, na których profesorowie gimnazjalni i starsi studenci wykładali historię i literature polską ${ }^{21}$.

W kręgu wpływów „Zetu” znalazło się tė̇ prawdopodobnie w początkach lat dziewięćdziesiątych XIX w. koło samokształceniowe polskich studentów funkcjonujące na Politechnice Lwowskiej, którego członkiem był m.in. późniejszy lider polskich socjalistów i premier Drugiej Rzeczypospolitej, Jędrzej Moraczewski. Koło - które sami jego działacze określali cokolwiek nazbyt ambitnie i szumnie mianem "Rządu Narodowego" - miało patriotyczne, ale i lewicowe oblicze. Zasady jego pracy były analogiczne do propagowanych przez „Zet”. Na powiązania z ZMP wskazywała też bliźniacza, hierarchiczna i zakonspirowana struktura koła ${ }^{22}$.

Na zachodzie Europy, w Genewie, $z$ inicjatywy zetowców powstało 25 grudnia 1887 r. jawne Zjednoczenie Towarzystw Młodzieży

20 F. Szymiczek, op. cit., s. 103-104.

${ }^{21}$ Więcej o „Eleuzis” por. J. Gaj, Główne nurty ideowe w ZHP w latach 19281939, Warszawa 1966, s. 29-31; J. Kwiatek, Nieznana korespondencja, „Eleuzis” na Górnym Ślasku, „Kwartalnik Opolski” 1988, nr 3-4, s. 89-123; J. Ko strzew s ki, op. cit., s. 69-71, 229-230. Materiały też w: BN, Rękopisy, akc. 16270, S. Szwe d ow ski, „Pisma Organizacji Młodzieży Narodowej przed pierwszą wojna ś światową do 1914 oraz zbiór odezw tejże organizacji (od 1910 r.)”, 5/II, brak paginacji.

${ }^{22}$ I. Florczak, Jędrzej Moraczewski. Socjalista, poset, legionista. Z autonomicznej Galicji do niepodległej Polski, Łódź 2009, s. 38-39. 
Polskiej Zagranica (ZTMPZ). Skupiało ono polskie organizacje studenckie, działające na wyższych uczelniach poza granicami państw zaborczych i pozostawało pod wpływami „Zetu”23. Początkowo obejmowało tylko organizacje polskie w Szwajcarii, następnie zaś i inne stowarzyszenia polskiej młodzieży akademickiej także $z$ terenu Niemiec.

Statut Zjednoczenia wskazywał jako cele: wzmacnianie jedności w życiu młodzieży polskiej za zagranicą i jej łączności z młodzieżą w kraju, utrzymywanie wśród młodych akademików jednolitej opinii w sprawach zasadniczych, wreszcie ułatwianie młodzieży samokształcenia. Pierwszym i długoletnim prezesem Zjednoczenia był Z. Miłkowski. Od 1903 r. archiwum ZTMPZ mieściło się w Rapperswilu. Zjednoczenie miało charakter powszechnej organizacji polskich studentów poza granicami kraju. Na jego forum od początku toczyła się walka ideologiczna między młodzieżą narodową a socjalistyczna, której towarzyszyło krystalizowanie się wspomnianych postaw. $Z$ czasem wykształciła się $\mathrm{w}$ organizacji jako dominująca postawa właściwa zetowcom po zerwaniu $z$ Liga Narodowa - połączenie wrażliwości społecznej $z$ idea narodowa i irredentystyczną.

W grudniu 1899 r. na XIII Zjeździe Zjednoczenia nastapił rozłam w organizacji. Wyłonił się wówczas z niej Związek Polskiej Młodzieży Postępowej (Unie Polskiej Młodzieży Postępowej), który objał przede wszystkim młodzież z zaboru rosyjskiego i Francji, gdy natomiast $\mathrm{w}$ dawnym TMPZ skupiała się młodzież $z$ ośrodków w Niemczech, Szwajcarii i z Małopolski. Zjednoczenie w tym nowym kształcie przetrwało do wybuchu Wielkiej Wojny ${ }^{24}$.

Z kolei w 1890 r. członkowie ZMP założyli w Lipsku tajny Związek Towarzystw Polskich w Niemczech "Unitas”, łączacy polskie konspiracyjne organizacje młodzieżowe działajace w Cesarstwie Niemieckim. W lipcu 1896 r. podległy „Zetowi” Związek „Unitas” zorganizował w Poznaniu zjazd delegatów kół samokształceniowych $z$ Wielkopolski ${ }^{25}$.

Zasadnicza działalność akademików Polaków w Berlinie, zwłaszcza po 1901 r., skupiła się w nieformalnych grupach i tajnych

23 B. Hillebrandt, op. cit., s. 18.

${ }^{24}$ F. Szymiczek, op. cit., s. 95; J. Lew and ow ski, Polacy w Szwajcarii, [w:] Polacy $w$ świecie. Polonia jako zjawisko społeczno-polityczne, cz. 2, red. A. Koprukowniak, W. Kucharski, Lublin 1986, s. 222.

25 J. Szews, op. cit., s. 28-29; T.W. N ow a cki, Szkic do dziejów Zetu, [w:] Zet $w$ walce o niepodległość i budowę państwa. Szkice i wspomnienia, red. T.W. Nowacki, Warszawa 1996, s. 45-46. 
strukturach podporzadkowanych „Zetowi”. Do takiego działania zmusiły młodzież władze pruskie, które nie pozwalały np. na swobodna działalność zalegalizowanego w 1878 r. Towarzystwa Naukowego Akademików Polaków w Berlinie. W stolicy cesarstwa działały już wówczas konspiracyjne grupy kierowane przez "Zet”. Ich członkowie spotykali się m.in. na tzw. obiadach czwartkowych organizowanych od stycznia 1903 r. przez Karola Rosego, późniejszego konsula generalnego Rzeczypospolitej w Berlinie w latach 1918-1924. Omawiano na nich kwestie natury politycznej, społecznej, kulturalnej itp. Zebrania te trwały do $1909 \mathrm{r.}^{26}$

Zetowcy mieli także pewne wpływy na Politechnice Gdańskiej. Przed wybuchem I wojny światowej studiowało tam kilkunastu Polaków. Tworzyli oni luźne zrzeszenie bez wyraźnej formuły organizacyjnej, które kontaktowało $z$ inteligencją polską w Gdańsku oraz organizowało spotkania towarzyskie i naukowe. W 1908 r. pod skrzydłami tego środowiska powstało towarzystwo śpiewacze „Lutnia”. W 1913 r. zrzeszenie nabrało organizacyjnej formy jako Związek Akademików Gdańskich. Impulsem utworzenia nowej organizacji były obchody rocznicy uchwalenia Konstytucji 3 maja wśród młodzieży polskiej w Gdańsku. W trakcie uroczystości mecenas Mieczysław Marchlewski - opiekun Zwiąku do wybuchu I wojny światowej, a zarazem działacz pozostajacy w bliskich kontaktach $z$ zetowcami - wygłosił przemówienie o znaczeniu majowej konstytucji. Członkowie kierowanej przezeń organizacji deklarowali prace na rzecz niepodległości Polski i działalność przeciw wynarodowieniu polskiej młodzieży w Gdańsku. Związek Akademików stawiał sobie za cel popularyzowanie polskiej kultury, wiedzy o literaturze polskiej, organizowanie odczytów, zakładanie kół śpiewaczych jako jedynie dozwolonych form stowarzyszeń oświatowych dla Polaków, wreszcie opiekę nad gimnazjum wejherowskim ${ }^{27}$.

$Z$ kolei wyrazem chęci i dążeń ze strony Związku Młodzieży Polskiej do utrzymywania kontaktu $z$ zetowcami, którzy po ukończeniu studiów opuszczali szeregi organizacji, było utworzenie w 1888 r. „Łączności” - struktury, która w założeniu miała skupiać byłych działaczy „Zetu” i prowadzić akcję propagandowa na rzecz sprawy polskiej. Zainicjowała ona m.in. wydawanie serii broszur, zatytułowanej $Z$ dzisiejszej doby. Szczególna aktywnością w budowaniu

${ }^{26}$ K. Ros e, Wspomnienia berlińskie, Warszawa 1932, s. 31-38.

27 S. Mikos, Polacy na politechnice $w$ Gdańsku $w$ latach 1904-1939, Warszawa 1987, s. 23-30. 
nowej organizacji wykazali się spośród zetowców m.in. Wacław Męczkowski, Józef Kamiński i Tomasz Rutkiewicz ${ }^{28}$.

Odmienna relację o genezie, znaczeniu i charakterze „Łączności” pozostawił Roman Dmowski. W jego ocenie organizacja ta miała zastępować Ligę Polska (dalej: LP), skupiając tych spośród byłych zetowców, którzy po opuszczeniu murów wyższych uczelni i wejściu w „dorosłe” społeczeństwo nie zostali zakwalifikowani do członkostwa w LP. Przywódca polskiego obozu narodowego wspominał: „Po paru latach istnienia Związku trzeba było rozstrzygnąć kwestię, co zrobić z ludźmi kończącymi wyższe szkoły i opuszczającymi szeregi ZMP. Wybitniejsi z nich zostawali członkami Ligi, niektórzy już na ławach uniwersyteckich, ale większość nie kwalifikowała się do tej organizacji, tak jak ja pojmowano. Wobec tego założono w Królestwie Kongresowym organizację pod nazwa "Eączność" nie mająca charakteru rewolucyjnego, przeznaczona do skupienia ludzi mniej więcej jednomyślnych w swych przekonaniach i zaprzężenia ich do prac obywatelskich, których nie można zupełnie jawnie prowadzić, oraz do wywierania wpływu na życie jawnych stowarzyszeń. Ta organizacja wykazała bardzo mała żywotność i prawie żadnej działalności nie umiała rozwinąć"

Z czasem „Łączność” postanowiono rozwiązać. Organizacja zakończyła działalność w 1893 r., a jej członków rozpoczęto wcielać do nowej struktury - Ligi Narodowej. Praktyczne przeprowadzenie tej reformy wzią na siebie R. Dmowski, który w ciagu pół roku przeprowadził osobiste rozmowy z kilkudziesięcioma ludźmi, którzy następnie weszli w skład nowej organizacji ${ }^{30}$.

"Zet" usiłował także wpływać na postawy młodzieży robotniczej i wiejskiej oraz „dorosłego” społeczeństwa, tworząc nowe konspiracyjne, patriotyczne organizacje. W 1901 r. założono Związek Młodzieży Rzemieślniczej im. Jana Kilińskiego (dalej: ZMR). Do najbardziej aktywnych działaczy „Zetu” wśród młodych rzemieślników i robotników należeli m.in. Mieczysław Bujalski (który pełnił funkcję kierownika Związku) i Przemysław Podgórski.

„Kilińszczacy” brali udział w akcji szkolnej i na własną rękę inspirowali strajki w szkołach zawodowych, niedzielnych, rzemieślni-

${ }^{28}$ T. Wolsza, Stowarzyszenie „Eacznośç" (1888-1893): u źródeł Ligi Narodowej, „Dzieje Najnowsze” 1987, nr 2, s. 3-35; R. Wa piński, Roman Dmowski, Lublin 1988, s. 53-54.

${ }^{29}$ M. Kułakow ski, Roman Dmowski w świetle listów i wspomnień, Dębogóra 2014, s. 152.

${ }^{30}$ Ibidem, s. 167. 
czych i handlowych. Związek Młodzieży Rzemieślniczej miał budzić świadomość narodową i krzewić ideę walki o wolną Polskę wśród młodzieży robotniczej, rzemieślniczej i urzędniczej. Miał strukturę wielostopniową i hierarchiczna. Naczelna władzą ZMR było walne zebranie, wybierajace radę organizacji oraz komitet wykonawczy. Struktura terenowa oparta była na dziesiątkach (kółkach). Każdy szeregowy członek dziesiątki stawał $z$ czasem na czele nowej dziesiątki. Działały on pod ogólną nazwą Organizacji Młodzieży Robotniczej. Struktury Związku podjęły działalność organizacyjną i formacyjną również wśród młodzieży żeńskiej. Organizacja rozrosła się w okresie rewolucji 1905 r., przybierając nazwę Narodowa Młodzież Rzemieślnicza i Robotnicza. Wewnętrzny krąg wtajemniczenia stanowili w niej najbardziej czynni, świadomi idei zetowych i dłużej zaangażowani w działalność członkowie środowiska zetowego ${ }^{31}$.

"Zet” skierował zarazem swoich działaczy, np. Jana Stanisława Jankowskiego, Józefata Bohuszewicza, Ludwika Skoczylasa i Gustawa Simona, w szeregi utworzonego w 1905 r. Narodowego Związku Robotniczego (dalej: NZR), co było zwiąane $z$ planami wykorzystania w przyszłości tej organizacji jako jawnej ekspozytury ZMP ${ }^{32}$. Kadrę kierownicza i trzon NZR mieli stanowić działacze inspirowanych przez zetowców środowisk Narodowej Młodzieży Robotniczej i Rzemieślniczej oraz ZMR. Narodowy Związek Robotniczy głosił hasło solidaryzmu narodowego. W okresie rewolucji lat 1905-1907 organizował wiece i demonstracje pod hasłami walki o interesy robotnicze i narodowe; zarazem przeciwstawiał się radykalnym, rewolucyjnym hasłom, jako godzacym w interes narodo$w^{33}$. Eksponowano przy tym - w organach prasowych, broszurach i ulotkach firmowanych przez NZR oraz podczas zorganizowanych przezeń manifestacji i zebrań - hasła narodowe i niepodległościo-

${ }^{31}$ M. Bujalski, Zwiąek im. Jana Kilińskiego (Narodowa Młodzież Robotnicza) 1901-1906, [Warszawa] 1930, s. 3-5; S. Ros zkow ski, Komisja Robotnicza „Zetu”, „Niepodległość”, Warszawa 1933, t. VII, z. 3, s. 361-380.

32 O wpływach Zetu w NZR por. T. Mon asterska, Narodowy Zwiazek Robotniczy 1905-1920, Warszawa 1973, s. 19-20, 89-91; J. Holzer, Naprawiacze, zetowcy i Zwiazek Patriotyczny, „Acta Universitatis Wratislaviensis” 1981, Historia 36, nr 543, s. 197; H. Kiepurska, Warszawa $w$ rewolucji 1905-1907, Warszawa 1974, s. 159-160.

${ }^{33}$ S. Kalabiński, F. Tych, op. cit., s. 165; G. Zackiewicz, Syndykalizm $w$ polskiej refleksji i rzeczywistości politycznej I połowy XX wieku, Kraków 2013, s. 122-126; J. To mas iew icz, Rewolucja narodowa. Nacjonalistyczne koncepcje rewolucji społecznej w Drugiej Rzeczypospolitej, Warszawa 2012, s. 52-53. 
we. Działacze Związku brali udział w licznych akcjach, które miały na celu spolszczenie instytucji i urzędów oraz nazw ulic, wreszcie ustanowienie polskiej szkoły ${ }^{34}$.

Zarówno Związek im. Jana Kilińskiego, jak i NZR wraz z „Zetem” zdecydowały się zerwać $z$ Liga Narodowa po burzliwym okresie rewolucji 1905 r., negując prorosyjską i kapitulancka, według nich, politykę LN i jawnego Stronnictwa Narodowo-Demokratycznego ${ }^{35}$.

Zetowcy odegrali też pewną rolę $\mathrm{w}$ procesie powstawania socjalistycznego Związku Robotników Polskich (dalej: ZRP). Został on utworzony w 1889 r., jeszcze przed wykrystalizowaniem się w ZMP podziału na „narodowców” i "socjalistów”, który - jak wiadomo - zaowocował rok później opuszczeniem szeregów „Zetu” przez pierwsza, liczną grupę zdeklarowanych sympatyków idei socjalistycznych. Wcześniej część zetowców uwrażliwionych na kwestie społeczne i walkę o interesy robotników bardzo aktywnie uczestniczyła w utworzeniu struktur ZRP. Grupie tej przewodził zetowy „radykał” Janusz Tański. Rok później jego związek ze środowiskiem "Zetu” uległ osłabieniu - nie tylko na skutek wewnętrznego sporu między „narodowa prawica” a "socjalistyczna lewica” ZMP, lecz także w rezultacie ukończenia przez niego studiów na Uniwersytecie Warszawskim i objęciu posady nauczyciela w Kielcach ${ }^{36}$.

Innym środowiskiem politycznym, w którym zetowcy mieli pewne wpływy, był ruch ludowy, kształtujaccy się na przełomie XIX i XX stulecia na ziemiach polskich. Efektem podjętych przez nich działań było m.in. powstanie w 1912 r. Narodowego Związku Chłopskiego. Do jego utworzenia przyczynił się w ogromnej mierze członek zetowej Centralizacji Aleksander Zawadzki ${ }^{37}$.

Wcześniej, jeszcze w 1901 r. z podobnych pobudek powstała z inspiracji „Zetu” Liga Oświaty Ludowej, a w 1902 r. Towarzystwo Pomocy Unitom (dalej: TPU) - organizacje społeczne, w których duży autorytet zdobył jeden $z$ najwybitniejszych działaczy zetowych Wiktor Ambroziewicz. Ich zadaniem było krzewienie oświaty i poczucia polskiej tożsamości narodowej wśród ludności chłopskiej. W przy-

${ }^{34}$ P. Samuś, Wasza kartka wyborcza jest silniejsza niż karabin, niż armata... Z dziejów kultury politycznej na ziemiach polskich pod zaborami, Łódź 2013, s. $49-51$.

35 B. Hillebrandt, op. cit., s. 17.

${ }^{36}$ F. Ty c h, Związek Robotników Polskich 1889-1892. Anatomia wczesnej organizacji robotniczej, Warszawa 1974, s. 107-108, 118-120; Międzynarodowa solidarność proletariatu, Londyn 1902, s. VI-VII.

${ }^{37}$ B. Hillebrandt, op. cit., s. 22. 
padku TPU akcja ta obejmowała obszary na wschodzie, zamieszkiwane przez ludność przedrozbiorowej Rzeczypospolitej o wyznaniu grekokatolickim, zmuszana przez administrację rosyjską do przyjęcia prawosławia. Zakładała organizowanie dla niej wszechstronnej pomocy materialnej i prawnej ${ }^{38}$.

Cele edukacyjne stawiało natomiast przed soba Towarzystwo Oświaty Narodowej (dalej: TON), zwane potocznie „Oświatą, utworzone ok. 1890 r. z inicjatywy „Zetu” i Ligi Polskiej. Jego działalność rozwinęła się zwłaszcza od 1894 r., obejmując ziemie polskie wszystkich trzech zaborów. Zetowcy aktywnie uczestniczyli w akcji oświatowej TON. Wspólnie $z$ wtajemniczonymi w działalność Towarzystwa petowcami organizowali przerzut literatury i pomocy szkolnych. Osobiście też brali udział w przemycie książek szkolnych i z zakresu literatury pięknej z Krakowa i Lwowa do Królestwa Polskiego. Z członkami „Petu” prowadzili kursy dla młodzieży wiejskiej i robotniczej $z$ miast, obejmujace naukę czytania, pisania i opanowanie podstawowych umiejętności matematycznych. Szczególnie jednak widoczny i znaczacy był udział w akcji kobiet-nauczycielek, po części sympatyzujących ze środowiskiem zetowym i jego hasłami ${ }^{39}$.

Z kolei na początku 1908 r. z inicjatywy Wawrzyńca Dajczaka, członka „Zetu” i studenta wydziału architektury Politechniki Lwowskiej, powstały Drużyny Bartoszowe. Zetowcy chętnie zgłaszali do nich akces. Brali również udział w wypracowaniu programu ideowego i modelu działania Drużyn. Nowa organizacja miała na celu przede wszystkim ukształtowanie wśród młodzieży polskiej wiejskiej ducha narodowego i niepodległościowego, etosu walki zbrojnej o państwo polskie. Członkowie Drużyn Bartoszowych wywodzili się $z$ lwowskiej młodzieży studenckiej (w tym wielu spośród środowiska „Zetu”), ale przede wszystkim z młodego pokolenia chłopów. Natomiast kadrę kierowniczą organizacji, skupioną w Radzie Naczelnej i Radzie Nadzorczej, stanowili w dużej większości młodzi akademicy (wśród nich zetowcy) z Lwiego Miasta. Drużyny Bartoszowe, mając swą stała siedzibę we Lwowie, rozwijały swe struktury terenowe początkowo wyłącznie w Małopolsce Wschodniej. $Z$ czasem jednak zwiększyły obszar swego działania na tereny Małopolski Zachod-

${ }^{38}$ Por. m.in. S. Biegański, Idea państwowa $w$ ruchu niepodległościowym w latach 1908-1914, „Niepodległość”, Londyn 1955, t. V, s. 84-93.

39 T.W. Nowacki, Zwycięska walka młodzieży o szkołe polska 1901-1917, „Niepodległość i Pamięć” 2007, nr 2, s. 58-59. 
niej, Śląska Cieszyńskiego oraz - w niewielkim stopniu - na ziemie zaboru rosyjskiego. W 1914 r. organizacja liczyła blisko 300 drużyn i do 10 tys. członków. Na przełomie lipca i sierpnia 1914 r. Drużyny Bartoszowe połączyły się pod egida Centralnego Komitetu Narodowego we Lwowie $z$ pozostajacymi pod wpływami obozu narodowego Polowymi Drużynami Sokoła. Warto podkreślić, że były pierwsza powstała na ziemiach polskich organizacja niepodległościową i paramilitarną młodzieży wiejskiej ${ }^{40}$.

W 1907 r. w "Zecie”, w związku z podjęciem uchwały o zerwaniu stosunków między ZMP i Ligą Narodową (której „Zet” był podporządkowany od 1887 r.), nastapił ferment ideowy. Przyczyną sporu, a następnie zerwania współpracy organizacyjnej stało się, jak wiadomo, negatywne stanowisko Ligi wobec strajku szkolnego w 1905 r., który był wszak największym osiagnnięciem organizacyjnym młodzieży zetowej i petowców, powodem do dumy działaczy ZMP i kluczowym elementem założycielskiej i historycznej legendy „Zetu”. Jednakże nawet po rozejściu się dróg „Zetu” i LN część zetowców krytykowała macierzysta, samodzielna już organizację z jednej strony za zbyt wstrzemięźliwy - ich zdaniem - i unikający zdecydowanej krytyki stosunek do programu i działalności Ligi, $z$ drugiej - za kunktatorstwo i niechęć do przyjęcia jednoznacznie irredentystycznego stanowiska i skupienia się na przygotowaniu społeczeństwa, a przede wszystkim młodzieży do walki zbrojnej o odzyskanie niepodległości.

Spór wewnątrz „Zetu” pociagnął za sobą rozłam. Część działaczy ZMP opuściło szeregi konspiracji zetowej i 13 marca 1909 r. utworzyło Organizację Młodzieży Niepodległościowej „Zarzewie”. Głównymi ośrodkami nowego stowarzyszenia stały się Lwów (gdzie mieściła się siedziba sztabu wojskowego „zarzewiaków”) i Kraków (miejsce urzędowania tzw. sztabu politycznego). Kierownictwo „Zarzewia” stanowiła Legia Niepodległości (Legia Niepodległościowa, „Elen”). Działacze „Zarzewia”, spodziewając się wybuchu wojny w Europie, główny wysiłek skierowali na kwestie wyszkolenia wojskowego młodzieży, tworząc we Lwowie i w Krakowie Polski Związek Wojskowy oraz organizując polski skauting. Równocześnie utrzymywali kontakty ze swymi kolegami pozostającymi w szeregach

40 Statut Towarzystwa Drużyny Bartoszowe we Lwowie, Lwów 1908, s. 3-5; Drużyny Bartoszowe. Przykazania Drużyniaka, [b.m. i d.w.] [I i II]. Więcej o Drużynach Bartoszowych por. m.in. Drużyny Bartoszowe 1908-1914, Lwów 1939, passim; Zarys dziejów wojskowości polskiej w latach 1864-1939, red. P. Stawecki, Warszawa 1990, s. 109. 
konspiracji zetowej, współpracując w przedsięwzięciach o charakterze politycznym i społecznym ${ }^{41}$.

Z kolei w 1908 r. powstał Polski Związek Wojskowy (dalej: PZW), grupujący sympatyków „Zarzewia”, NZR i „Zetu”. Komendantem naczelnym PZW został Jerzy Bujalski, zastapiony w 1909 r. przez Mieczysława Norwid-Neugebauera. Celem organizacji było przygotowanie i mobilizacja sił zbrojnych narodu do walki o niepodległość, w szczególności przygotowanie i wyćwiczenie przyszłego korpusu oficerskiego na potrzeby przyszłej wojny. Początkowo PZW działał tylko w okręgu krakowskim, stanowiąc stosunkowo nieliczną strukturę. Następnie dzięki intensywnemu napływowi i pracy „zarzewiaków” rozszerzył wpływy na okręg lwowski. Polski Związek Wojskowy istniał do 1910 r., gdy na zjeździe młodzieży „zarzewiackiej” w Krakowie w dniach 3-4 października podjęto decyzję o jego rozwiazaniu. W jego miejsce zjazd ustanowił tajna organizację wojskowa pod nazwą Armia Polska (dalej: AP). Uczestnicy obrad uchwalili też jej statut. Działaniami AP - podobnie jak wcześniej PZW - kierowała Komenda Naczelna. Komendantem Naczelnym został M. Norwid-Neugebauer. W 1911 r. konspiracyjna Armia Polska powołała legalne organizacje paramilitarne Polskie Drużyny Strzeleckie (dalej: PDS). W ich utworzeniu i działalności największe

${ }^{41}$ Szerzej o genezie i działalności „Zarzewia” por. A. Stebelski, Zarzewie 1909-1915, [w:] Nasza walka o szkołe polska 1901-1917, red. B. Nawroczyński, t. I, Warszawa 1932, s. 187-201; Zarzewie 1909-1920. Wspomnienia i materiały, oprac. A. Garlicka, Warszawa 1973, s. 11-82; W. Studnicki, Z przeżyć i walk, Warszawa 1928, s. 267-268; F. Młynarski, Wspomnienia, Warszawa 1971, s. 45-49; T. Katelb a ch, op. cit., s. 13-15; J. Rakow s ki, op. cit., s. 17-19; S. Biegańs ki, Idea państwowa..., s. 84-93; W. Potkański, Ruch narodowo-niepodległościowy $w$ Galicji przed 1914 rokiem, Warszawa 2002, s. 63-65, 88-118; id e m, Zawiazanie, działalność oraz wystapienie Związku Młodzieży Polskiej z Narodowej Demokracji w 1909 r. i utworzenie „niezależnego Zetu”, „Dzieje Najnowsze” 1998, $\mathrm{nr}$ 4, s. 19; i d e m, Spór o oblicze ideowe polskiego skautingu przed pierwsza wojna światowa, „Przegląd Historyczny” 2003, z. 4, s. 398-410; A. Garlicki, Od maja do Brześcia, Warszawa 1985, s. 19; K. Rataj ska, op. cit., s. 215-231. D. Pau luk, Program wychowania narodowego "młodych do młodych" na łamach czasopisma „Zarzewie” (1909-1914), „Polska Myśl Pedagogiczna” 2015, nr 1, s. 186-188; T. Nałęcz, Eugeniusz Kwiatkowski, [w:] KSAP XX lat, red. H. Samsonowicz, Warszawa 2010, s. 126-127; A. Garlicki, Dylematy polityka, [w:] E. Kwiatkows ki, Dysproporcje. Rzecz o Polsce przeszłej i obecnej, oprac. A. Garlicki, Warszawa 1989, s. 5-10; "Zarzewie” [jednodniówka z okazji zjazdu w 25-lecie „Zarzewia”, polskich drużyn strzeleckich i skautingu 1909-1934], red. I. Płażewski, Warszawa 1934, passim; A. M a s s als ki, Generał Józef Haller wobec ruchu harcerskiego, [w:] Generał Józef Haller - patriota, żołnierz, wychowawca młodzieży, społecznik, Warszawa 2014, s. 23; A. Borkiewicz-Celińska, Początki skautingu na ziemiach polskich, „Więż” 1978, nr 10, s. 81-90. 
zasługi położyli ponownie M. Norwid-Neugebauer, a także Marian Żegota-Januszajtis, Henryk Bagiński, Wacław Tokarz oraz Eugeniusz Romer. Za politycznego kierownika ruchu uznawano Feliksa Młynarskiego. W 1914 r. organizacja dysponowała 80 drużynami w Galicji, 20 drużynami na terenie Królestwa Polskiego, pięcioma drużynami w Austrii, pięcioma drużynami w Poznańskiem i trzema drużynami na Ukrainie. PDS liczyły wówczas łącznie ok. 6 tys. ludzi. $Z$ organizacją sympatyzowały góralskie drużyny wojskowe, które na zjeździe w Nowym Targu w dniu 4 maja 1913 r. utworzyły Związek Drużyn Podhalańskich ${ }^{42}$.

W 1912 r., w wyniku widocznego zwiększenia się napięcia międzynarodowego, doszło do wyraźnego ożywienia w polskim obozie irredentystycznym. W dniach 25-26 sierpnia 1912 r. odbyło się poufne zebranie przedstawicieli organizacji niepodległościowych, zwołane $z$ inicjatywy działaczy PPS-Frakcji Rewolucyjnej. Powołano wówczas Polski Skarb Wojskowy i wybrano jego tymczasowy zarząd. Natomiast 10 listopada 1912 r. odbył się zjazd delegatów stronnictw politycznych. $Z$ zaboru rosyjskiego przybyli członkowie PPS, NZR, NZCh, Związku Niepodległości (Organizacji Niepodległościowej Inteligencji), $z$ zaboru austriackiego - Polskiej Partii Socjalno-Demokratycznej Galicji i Śląska Cieszyńskiego, Polskiego Stronnictwa Postępowego i Stronnictwa Niezawisłych Ludowców. Utworzono konfederację stronnictw niepodległościowych i powołano organ kierowniczy dla przygotowań wojskowych - Komisję Tymczasowa, złożona po jednym delegacie $z$ wymienionych stronnictw $z$ prawem rozszerzenia udziału i $z$ innych stronnictw niepodległościowych. Tymczasowa Komisja Skonfederowanych Stronnictw Niepodległościowych, o której mowa, miała kierować polskimi organizacjami militarnymi, Polskim Skarbem Wojskowym, a w przypadku wojny wyłonić $z$ siebie Rząd Narodowy ${ }^{43}$. Zetowcy uczestniczyli

${ }^{42}$ F. Młynarski, op. cit., s. 452; E. Kozłowski, M. Wrzosek, Dzieje oręża polskiego 1794-1938, Warszawa 1973, s. 322-328; S. Aks a mitek, Generał Józef Haller. Zarys biografii politycznej, Katowice 1989, 27; B. Hillebrandt, op. cit., s. 24-26, 17; H. Bagińs ki, U podstaw organizacji Wojska Polskiego 1908-1914, Warszawa 1935, s. 21-23, 147; Zarys dziejów wojskowości polskiej w latach 1864-1939, red. P. Stawecki, Warszawa 1990, s. 109; M. W alak, Niepodległościa naznaczeni. Z dziejów powstania i walk III Brygady Legionów Polskich 1915-1917, Bełchatów 2010, s. 33-35.

43 A. Garlicki, Geneza Legionów. Zarys dziejów Komisji Tymczasowej Skonfederowanych Stronnictw Niepodległościowych, Warszawa 1964, s. 64; M. W alak, op. cit., s. 28-29. 
w porozumieniu jako działacze NZCh i NZR. Należeli też, jak wiadomo, do oddziałów Związku Strzeleckiego i Towarzystwa „Strzelec”.

W atmosferze zadrażnień i rywalizacji między konkurentami w łonie obozu irredentystycznego członkowie ekspozytur i organizacji pochodnych "Zetu” wystapili jako pryncypialni zwolennicy samodzielności wobec Wiednia i opuścili TKSSN. Zarzucali jej również (a później Komisji Skonfederowanych Stronnictw Niepodległościowych) zbyt jednostronna, lewicowa orientację polityczna. Znacząca pozycję działaczy stowarzyszeń związanych z ZMP w obozie irredentystycznym potwierdziły liczne echa i komentarze, które wywołali swoją secesją $z$ jego szeregów.

Równocześnie członkowie ekspozytur „Zetu” nie rezygnowali zarówno $z$ prób dyskusji $z$ pozostałymi środowiskami tworzącymi polski obóz niepodległościowy w Galicji - proponując korektę linii politycznej w kierunku nadania jej bardziej ogólnonarodowego, propaństwowego i ponadpartynego charakteru - jak i ze spektakularnych gestów protestu w obliczu „proaustriackiego serwilizmu” reszty środowisk irredentystycznych.

Jedna $z$ okazji do zademonstrowania przez zetowców i „zarzewiaków" sprzeciwu wobec nadmiernej, ich zdaniem, ugodowości ugrupowań skupionych w Komisji Skonfederowanych Stronnictw Niepodległościowych wobec „polityki Habsburgów” stał się ogólnopolski festyn strzelecki, przygotowany w Wiedniu $z$ okazji jubileuszu cesarza Franciszka Józefa I. Zaproszenie na uroczystości wiedeńskie otrzymał komendant krakowskiego okręgu „Strzelca” Mieczysław Trojanowski, jednak decyzja w tej sprawie nie zapadła od razu. Józef Piłsudski, poinformowany o tym telegraficznie we Lwowie, początkowo wahał się, czy należy skorzystać $z$ tej propozycji, ponieważ obawiał się, że zostałoby to niemile przyjęte przez galicyjska opinię publiczna, tym bardziej że inne polskie organizacje paramilitarne odmówiły udziału w wiedeńskiej imprezie.

Po przyjeździe Piłsudskiego do Krakowa 22 maja 1914 r. na wspólnej naradzie $z$ innymi działaczami postanowiono skorzystać z zaproszenia i wysłać pododdział strzelców do Wiednia. W dniu ich wyjazdu 30 maja 1914 r. na dworcu w Krakowie doszło do awantur, ponieważ przeciwni udziałowi w owej imprezie drużyniacy urządzili głośną demonstrację. Działacze Drużyn Strzeleckich zarzucili Związkowi Strzeleckiemu polityczne kapitulanctwo, a KSSN uprawianie polityki austrofilskiej. Później dyskutowali o tym na spotkaniach 
działacze środowiska „Strzelca” i współpracowników Piłsudskiego $z$ drużyniakami ${ }^{44}$.

Tak pisał o tych wydarzeniach Walery Sławek do Piłsudskiego w liście z 31 maja 1914 r.: „Wczorajsza depeszę wysłałem do Ciebie po rozmowie $z$ drużyniakiem [Stanisławem] Długoszem, który przyleciał $z$ dworca zdenerwowany i zaczął mnie prosić, by koniecznie zawrócić wiedeńską ekspedycję. Gdybym był na dworcu w chwili odjazdu i widział, co się tam działo, tobym tam zapewne na własna odpowiedzialność poradził "Rysiowi" [Mieczysław Trojanowski - P.W.] [...] nie jechać [...]. Kawał, jaki zaszedł, był bardzo przykry: na dworcu przed pociagiem zebrali się ubrani po cywilnemu drużyniacy (jeden tylko był w mundurze) [...]. Kiedy przechodził nasz oddział, zaczęli krzyczeć: "Zdjąć orzełki z czapek" itd. Doszło do karczemnych burd i scen. Awanturujących się z obu stron mitygowała policja" 45 .

W latach 1886-1914 Związek Młodzieży Polskiej „Zet”, pozostając organizacja ściśle zakonspirowana, rozszerzył swoją strukturę na ziemie polskie wszystkich trzech zaborów oraz na ośrodki akademickie i skupiska studiującej młodzieży polskiej w Rosji i Europie Zachodniej. Zetowcy, dażac do pozyskania wpływu na postawy ideowe i działalność pokolenia młodych Polaków, prowadzili konsekwentna, szeroko zakrojona prace organizacyjna, obejmujaca zarówno ziemie polskie pod zaborami, jak i zagranicę, której celem było zakładanie, inspirowanie bądź włączanie się w działalność licznych organizacji akademickich, szkolnych - uczniowskich oraz młodzieży robotniczej, wreszcie - nakierowanych na środowiska wiejskie. Nie poprzestając na pracy formacyjnej w młodym pokoleniu Polaków, członkowie ZMP starali się również zakładać, inspirować programowo bądź penetrować istniejące organizacje "dorosłego" społeczeństwa - zarówno mające charakter stowarzyszeń kulturalno-oświatowych, jak i partii politycznych; tajne, jak również funkcjonujące jawnie.

Wspomniane poczynania zetowców prowadziły do wytworzenia złożonej, obejmującej różne pokolenia i środowiska społeczne sieci organizacji o charakterze konspiracyjnym i jawnym, inspirowanych przez działajacych w ich szeregach, należących do środowisk kierowniczych, a często założycielskich zetowców. $Z$ zetowych inspi-

${ }^{44}$ P. Samuś, Walery Sławek. Droga do niepodległej Polski, Płock 2000, s. 356-357.

${ }^{45}$ Ibidem, s. 357. 
racji programowych i dotyczacych działalności niewtajemniczeni członkowie ekspozytur nie zdawali sobie sprawy.

Znajomość struktury wzajemnych powiązań między ZMP i „organizacjami zewnętrznymi” pozwala zrozumieć fenomen żywotności zetowej konspiracji na ziemiach polskich i zagranica przez ponad trzy dekady, dzielące jej założenie i odzyskanie przez Polskę niepodległości. Idee programowe, strategia polityczna i taktyka działania „Zetu” były wypracowywane w stosunkowo waskim, zaufanym gronie przywódczym konspiracji, którego członkowie znali się dobrze, a niejednokrotnie połączeni byli również więzami osobistej przyjaźni. Ograniczało to ewentualne spory i kontrowersje, a co za tym idzie - możliwość wewnętrznego rozbicia środowiska. $Z$ drugiej strony taktyka działania za pośrednictwem ekspozytur chroniła jądro kierownicze ZMP (liderów, przywódców, ideologów, twórców koncepcji programowych i autorów taktyki) nawet $\mathrm{w}$ przypadku represji spadających na organizacje „zewnętrzne”: zarówno ekspozytury tajne - w wyniku dekonspiracji przez agentury i policje państw zaborczych, jak i legalne - w przypadku podjęcia przez nie działań zbyt radykalnych $z$ punktu widzenia zaborców.

\section{Bibliografia}

\section{ŹRódea ARCHIWALNe}

Biblioteka Narodowa w Warszawie

Rękopisy, akc. 16272, S. Szwedowski, „Materiały do Zetu (listy Ignacego Nowaka do S. Szwedowskiego)".

Rękopisy, akc. 16270, S. Szwedowski, „Pisma Organizacji Młodzieży Narodowej przed pierwszą wojną światowa do 1914 oraz zbiór odezw tejże organizacji (od 1910 r.)".

Biblioteka Zakładu Narodowego im. Ossolińskich we Wrocławiu

Rękopisy, sygn. 15951 II, S. Szwedowski, „Początki pamiętnika po raz IV-ty”.

\section{$\dot{Z}_{\text {RÓDEA DRUKOWANE }}$}

Bielak J., Z odległości lat. Wspomnienia i sylwetki, Kraków 1979.

Drużyny Bartoszowe 1908-1914, Lwów 1939.

Drużyny Bartoszowe. Przykazania Drużyniaka, [b.m. i d.w.] [I i II].

Kostrzewski J., Z mego życia. Pamiętnik, Wrocław 1970. 
Kułakowski M., Roman Dmowski w świetle listów i wspomnień, Dębogóra 2014.

Kwiatek J., Nieznana korespondencja „Eleuzis” na Górnym Ślasku, „Kwartalnik Opolski", 1988, nr 3-4, s. 89-123.

Młynarski F., Wspomnienia, Warszawa 1971.

Rose K., Wspomnienia berlińskie, Warszawa 1932.

Statut Towarzystwa Drużyny Bartoszowe we Lwowie, Lwów 1908.

Stebelski A., Zarzewie 1909-1915, [w:] Nasza walka o szkołe polska 1901-1917, red. B. Nawroczyński, t. I, Warszawa 1932, s. 187-201.

Studnicki W., Z przeżyć i walk, Warszawa 1928.

„Zarzewie” [jednodniówka z okazji zjazdu w 25-lecie „Zarzewia”, polskich drużyn strzeleckich i skautingu 1909-1934], red. I. Płażewski, Warszawa 1934.

Zarzewie 1909-1920. Wspomnienia i materiały, oprac. A. Garlicka, Warszawa 1973.

\section{OpRacowania}

Aksamitek S., Generał Józef Haller. Zarys biografii politycznej, Katowice 1989.

Bagiński H., U podstaw organizacji Wojska Polskiego 1908-1914, Warszawa 1935

Baliński W., Człowiek w cieniu. Tadeusz Pełczyński. Zarys biografii, Kraków 1994.

Biegański S., Idea państwowa $w$ ruchu niepodległościowym $w$ latach 1908-1914, „Niepodległość”, Londyn 1955, t. V, s. 84-93.

Borkiewicz-Celińska A., Początki skautingu na ziemiach polskich, „Więź” 1978, nr 10, s. 81-90.

Bujalski M., Zwiazek im. Jana Kilińskiego (Narodowa Młodzież Robotnicza) 19011906, [Warszawa] 1930.

Demel C., Z genezy Związku Młodej Polski w Wielkopolsce, „Studia i Materiały do Dziejów Wielkopolski i Pomorza" 1977, t. XII, z. 24, s. 158-163.

Florczak I., Jędrzej Moraczewski. Socjalista, poseł, legionista. Z autonomicznej Galicji do niepodległej Polski, Łódź 2009.

Gaj J., Główne nurty ideowe w ZHP w latach 1928-1939, Warszawa 1966.

Garlicki A., Dylematy polityka, [w:] E. Kwiatkowski, Dysproporcje. Rzecz o Polsce przeszłej i obecnej, oprac. A. Garlicki, Warszawa 1989, s. 5-10.

Garlicki A., Geneza Legionów. Zarys dziejów Komisji Tymczasowej Skonfederowanych Stronnictw Niepodległościowych, Warszawa 1964.

Garlicki A., Od maja do Brześcia, Warszawa 1985.

Halczak B., Towarzystwo Tomasza Zana w latach 1899-1914, Zielona Góra 1996.

Hillebrandt B., Polskie organizacje młodzieżowe XIX i XX wieku. Zarys historii, Warszawa 1986.

Holzer J., Naprawiacze, zetowcy i Zwiazek Patriotyczny, „Acta Universitatis Wratislaviensis" 1981, Historia 36, nr 543, s. 195-203.

Jaruzelski J., Stanisław Cat-Mackiewicz 1896-1966. Wilno-Londyn-Warszawa, Warszawa 1994. 
Kalabiński S., Tych F., Czwarte powstanie czy pierwsza rewolucja. Lata 19051907 na ziemiach polskich, Warszawa 1969.

Katelbach T., Zet, „Zeszyty Historyczne” [Paryż] 1968, z. 13, s. 3-54.

Kiepurska H., Warszawa w rewolucji 1905-1907, Warszawa 1974.

Kozłowski E., Wrzosek M., Dzieje oręża polskiego 1794-1938, Warszawa 1973.

Lewandowski J., Polacy w Szwajcarii, [w:] Polacy w świecie. Polonia jako zjawisko społeczno-polityczne, cz. 2, red. A. Koprukowniak, W. Kucharski, Lublin 1986, s. 213-236.

Markwicz A., 100 lat historii TTZ, Londyn 1975, s. 99.

Massalski A., Generał Józef Haller wobec ruchu harcerskiego, [w:] Generał Józef Haller-patriota, żołnierz, wychowawca młodzieży, społecznik, Warszawa 2014, s. 22-35.

Mikos S., Polacy na politechnice $w$ Gdańsku w latach 1904-1939, Warszawa 1987.

Monasterska, Narodowy Zwiazek Robotniczy 1905-1920, Warszawa 1973.

Nałęcz T., Eugeniusz Kwiatkowski, [w:] KSAP XX lat, red. H. Samsonowicz, Warszawa 2010, s. 125-144.

Nowacki T.W., Szkic do dziejów Zetu, [w:] Zet $w$ walce o niepodległość i budowe państwa. Szkice i wspomnienia, red. T.W. Nowacki, Warszawa 1996, s. 21-292.

Nowacki T.W., Zet-ideowy kręgosłup ZPMD, [w:] Związek Polskiej Młodzieży Demokratycznej podczas II Rzeczypospolitej i II wojny światowej, red. J. Pietrusza, Kraków 1998, s. 30-38.

Nowacki T.W., Zwycięska walka młodzieży o szkołe polska 1901-1917, „Niepodległość i Pamięć” 2007, nr 2, s. 37-91.

Pauluk D., Program wychowania narodowego "młodych do młodych" na łamach czasopisma „Zarzewie” (1909-1914), „Polska Myśl Pedagogiczna” 2015, nr 1, s. $186-188$.

Potkański W., Ruch narodowo-niepodległościowy w Galicji przed 1914 rokiem, Warszawa 2002.

Potkański W., Spór o oblicze ideowe polskiego skautingu przed pierwsza wojna światowa, „Przegląd Historyczny” 2003, z. 4, s. 398-410.

Potkański W., Zawiązanie, działalność oraz wystapienie Zwiazku Młodzieży Polskiej z Narodowej Demokracji w 1909 r. i utworzenie „niezależnego Zetu”, „Dzieje Najnowsze” 1998, nr 4, s. 3-20.

Rakowski J., Zetowcy i piłsudczycy (1), „Zeszyty Historyczne” [Paryż] 1981, z. 54, s. 3-39.

Ratajska K., Dziedzice filomatyzmu, Wrocław 1987.

Roszkowski S., Komisja Robotnicza „Zetu”, „Niepodległość”, Warszawa 1933, t. VII, z. 3, s. 361-480.

Samuś P., Walery Sławek. Droga do niepodległej Polski, Płock 2000, s. 356-357.

Samuś P., Wasza kartka wyborcza jest silniejsza niż karabin, niż armata... Z dziejów kultury politycznej na ziemiach polskich pod zaborami, Łódź 2013.

Socha J., Czasopisma Zwiazku Towarzystw Tomasza Zana, „Rocznik Historii Prasy Polskiej" 2002, z. 1, s. 59-68. 
Szews J., Filomaci pomorscy. Tajne zwiąki młodzieży polskiej na Pomorzu Gdańskim $w$ latach 1830-1920, Warszawa 1992.

Szymiczek F., Stowarzyszenia akademickie polskiej młodzieży górnoślaskiej we Wrocławiu 1863-1918, Wrocław-Warszawa-Kraków 1963.

Ślaski K., Toruński proces filomatów pomorskich w 1901 roku, [w:] Filomaci pomorscy. Księga pamiatkowa Sesji Naukowej oraz Zjazdu Filomatów w Wejherowie w dniu 20 maja 1972 roku, oprac. J. Szews, Gdańsk 1975, s. 6-12.

Tomasiewicz J., Rewolucja narodowa. Nacjonalistyczne koncepcje rewolucji spoŁecznej w Drugiej Rzeczypospolitej, Warszawa 2012.

Tusiński P.A., Narodowa Demokracja $w$ guberni radomskiej $w$ latach 1893-1907, [w:] Dziedzictwo rewolucji 1905-1907, red. A. Żarnowska i in., WarszawaRadom 2007, s. 301-327.

Tych F., Zwiazek Robotników Polskich 1889-1892. Anatomia wczesnej organizacji robotniczej, Warszawa 1974.

Walak M., Niepodległościa naznaczeni. Z dziejów powstania i walk III Brygady Legionów Polskich 1915-1917, Bełchatów 2010.

Wapiński R., Pokolenia Drugiej Rzeczypospolitej, Wrocław 1991.

Wapiński R., Roman Dmowski, Lublin 1988.

Wierusz A., Ruch niepodległościowy kształcacej się młodzieży b. zaboru pruskiego, [w:] Pamiętnik I Zjazdu Niepodległościowców byłej dzielnicy pruskiej w Poznaniu w dniu 14 I 1934 roku, Poznań 1935, s. 48-54.

Wolna H., Komendant „Rakoczy”, Warszawa 1985.

Wolsza T., Stowarzyszenie „Łącznośc” (1888-1893): u źródeł Ligi Narodowej, „Dzieje Najnowsze” 1987, nr 2, s. 3-35.

Wołos M., „Ojczyźnie służy”. Damian Stanisław Wandycz (1892-1974), BełchatówKraków-Warszawa 2015.

Zackiewicz G., Syndykalizm w polskiej refleksji i rzeczywistości politycznej I połowy XX wieku, Kraków 2013.

Zarys dziejów wojskowości polskiej w latach 1864-1939, red. P. Stawecki, Warszawa 1990.

Przemyseaw Waingertner

\section{Agencies and influence of the Associaton of the Polish Youth "Zet" (Związek Młodzieży Polskiej „Zet") during the period of the Partitions of Poland (1886-1914)}

IN 1886, at the University of Warsaw was established a secret Association of the Polish Youth „Zet” (APY). In the three decades it has become well organised and operating structure, with its outposts in the academic centres, where they studied the Poles - in Polish lands all three partitions, in Russia and in Western Europe. The program of APY called for young people to fight for an independent, 
united, democratic, self-governing, socially equitable and tolerant republic. The members of APY, in order to affect young Poles, ran on an activity involving the creation and inspiration of the academic unions and the associations of students, youth workers and peasants. They try to penetrate the existing structure of the "adult” society. Among these organizations were: „Red Rose”, „X”, „Pet”, National Groups, the National Youth Organization, „Eleuzis”, Union of Polish Societies in Germany „Unitas”, the Union of Societies of the Polish Youth Abroad, Union of Youth Craft, National Union of Workers, the National Union of Peasants, People Education League, National Education Association and the team Bartosz's Troops. They expanded the influence of APY.

Keywords: history of Poland $19^{\text {th }}-20^{\text {th }}$ century, social and political movements on the Polish lands, Association of the Polish Youth "Zet”. 